\title{
Maintaining the Grape Quality on Organically Grown Vines (Vitis vinifera L.) at Vineyard Condition under Temperate Climate of Konya Province
}

\author{
Ferhan K. Sabir ${ }^{1}$ - Ali Sabir ${ }^{1} \cdot$ Sevil Unal ${ }^{1}$ \\ Received: 12 January 2021 / Accepted: 2 July 2021 / Published online: 23 July 2021 \\ (c) Springer-Verlag GmbH Deutschland, ein Teil von Springer Nature 2021
}

\begin{abstract}
Organically produced conventional products have gained great attention in accordance with the increasing awareness on healthy foods as well as improvements in living standards. Environment friendly strategies to extend the quality of grapes after commercial maturity provide healthy and profitable sustainability in market chain. In the present study, possibilities to maintain the quality of grape clusters on grapevines without any chemical treatments have been studied under vineyard conditions in temperate climate characteristics of Konya Province in Central Anatolia. Grape clusters of 'Alphonse Lavallée' and 'Narince', one of the most popular conventional grape cultivar in Turkey, were kept on the vines trained with bilateral cordon system. The vines were drip irrigated during the hot summer and the vine canopy was covered with black nets after veraison to protect from the birds, hail and climatic extremities. After commercial maturity, twelve cluster samples per cultivar were collected with monthly intervals to investigate the changes in quality. Up to the 3rd sampling date (at the end of November 2019), little losses in quality features were determined in both cultivars. At the end of the study, at 4th moth (December), significant decay incidences were observed with similar patterns in cultivars. General findings demonstrated that the grape clusters could be maintained on grapevines under intact condition of the cool autumn season in temperate zone by protecting them from the external damages using convenient protective materials up to three or four months depending on the response of cultivars to environmental variables.
\end{abstract}

Keywords Grapevines $\cdot$ Healthy foods $\cdot$ Grape quality $\cdot$ Quality maintenance

\section{Erhaltung der Beerenqualität bei ökologisch angebauten Reben (Vitis vinifera L.) durch Belassen der Trauben an der Rebe bei gemäßigten Klimabedingungen der Provinz Konya}

Schlüsselwörter Weintrauben · Gesunde Lebensmittel · Traubenqualität · Qualitätserhaltung

\section{Introduction}

World population growth indicates that food supplies would need to increase by $60 \%$ in order to meet the food demand in 2050 (Alexandratos and Bruinsma 2012). World losses of agricultural products during postharvest are $10-30 \%$, and an estimated rate for grape is $27 \%$ (Romanazzi et al. 2007). In order to maintain the ever-increasing food de-

Ali Sabir

asabir@selcuk.edu.tr

1 Agriculture Faculty Horticulture Department, Selcuk University, Konya, Turkey mand, availability and accessibility of agricultural products can be improved by increasing the productivity, enhancing distribution, extending the postharvest quality, and reducing the losses (Kader 2002). Thus, reduction of the postharvest quality losses of food is an essential strategy of ensuring future global food security. Grapes are one of the most commonly cultivated agricultural products around the world with a great variability in utilization such as wine, raisin, fresh table grapes, vinegar, and juice (grape must). Table grapes, as non-climacteric commodities with a relatively low rate of physiological activity (Crisosto et al. 2001), are subject to postharvest losses during storage and transport ( $\mathrm{Li}$ et al. 2015), resulting in cluster stem drying, berry shattering, and shriveling of berries (Sabir and Sabir 
Fig. 1 Photos from experimental vineyard (left: Protecting the clusters against biotic and abiotic factors, 'Alphonse Lavallée' example; right: 'Narince' clusters on date 30.11 .2019 )
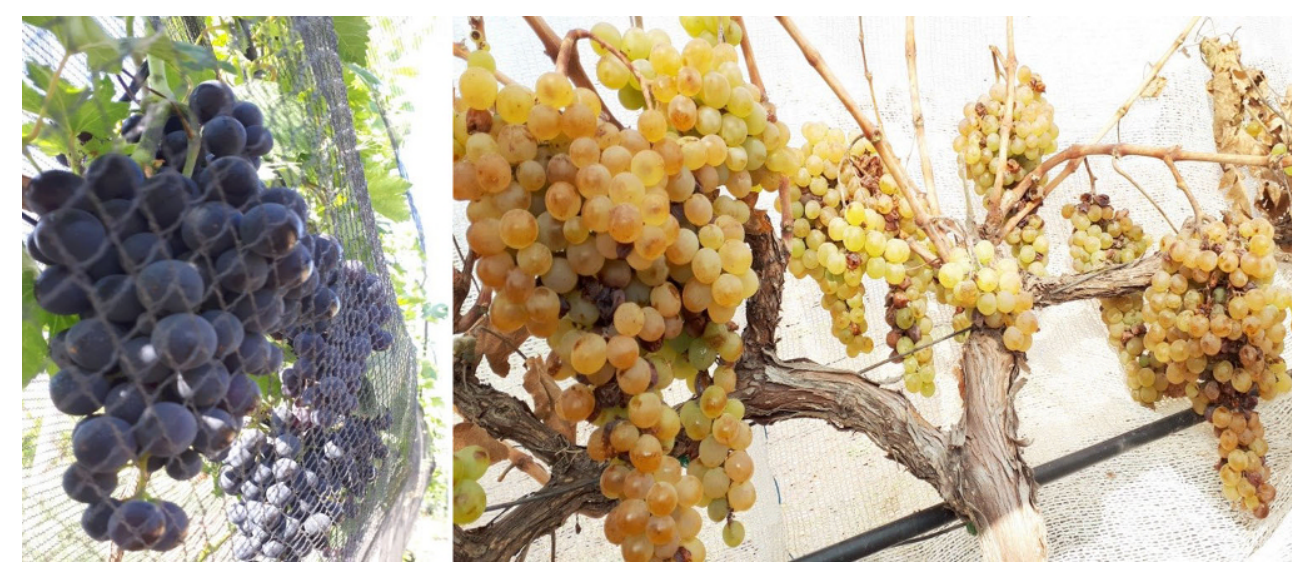

2013). Commercially, $\mathrm{SO}_{2}$ fumigation is still the common process to maintain grape quality due to its significant effect on grape berry diseases (Lee et al. 2015). But, sulphur residues are dangerous to allergic people and $\mathrm{SO}_{2}$ application may result in sulphurous flavor to the berry. There are many effective methodologies for extending postharvest quality of grapes. Cold storage, drying (raisin), juice freezing, canning, pickling, or fermenting into wine or vinegar are certain ways for conserving the grapes. Recently there has been a growing interest in traditional foods handled without chemical treatments with an increasing health and environment consideration. Besides, some traditional methods of preserving food have been shown to have a lower energy input and carbon footprint, when compared to modern methods. Traditional food conserving methods are generally depending on the climatic conditions of orchards or vineyards. In Turkey, the growers in villages have historical experiences in grape growing and conservation. One of the ways they use is maintaining the grape clusters on vines with various coverage materials. Although this practice has long been employed by grape growers around the mountainous villages of Mediterranean Region, there is, interestingly, insufficient available experimental data on this subject, except for a few regional trials. Theoretically, it is possible that biochemical and organoleptic qualities of grapes could be increased by delaying harvest up to a certain time of the season, while excessive delay could inevitably reduce final grape quality. Deciding the most convenient harvest time for the best quality and higher market value from their sale (Piazzola et al. 2016), necessitate the careful consideration of certain factors one of which may be directly related to berry resistance during on-vine maintenance. Therefore, the present investigations were performed to study the possibilities of maintaining the grape cluster quality of two different cultivars (Vitis vinifera L.) on vines at vineyard condition under temperate climate condition of Konya Province.

\section{Materials and Methods}

\section{Growth Condition}

The study was conducted on 5-7-year-old healthy and productive vines of 'Alphonse Lavallée' and 'Narince' grape cultivars. The experimental vineyard was located in Konya Province, Turkey $\left(38^{\circ} 01.7850 \mathrm{~N}, 032^{\circ} 30.5460 \mathrm{E}, 1158 \mathrm{~m}\right.$ above sea level). The vines were planted in east-west oriented rows with spacing of $2 \mathrm{~m} \times 3 \mathrm{~m}$. Agricultural practices were performed similar to common practices of local growers. In canopy management, shoot positioning was done according to the unique growth habits of each cultivar in a vertical shoot positioned trellis system. The vines received the same cultural practices, such as weed control, pruning and drip irrigation. After the onset of berry ripening (veraison), the grapevine canopies were totally covered with bird net up to the end of study to protect them from bird, hail and storm (Fig. 1).

Cluster sampling was commenced when the berries attain a total soluble solid value of commercial and traditional experiences. Afterwards, periodical samplings were performed with one month intervals to reveal the biochemical changes and decay incidence of the grapes. A total of nine clusters per sampling date of each cultivar were randomly harvested from the vines.

\section{Decay Incidence}

Berry decay was quantified by counting the number of decayed berries in each cluster, multiplying the total number of decayed berries per replication by the average berry size, and calculating the percentage of decayed berries (Sabir and Sabir 2017). 


\section{Skin Rupture and Berry Detachment Forces}

A total of forty five representative berries per treatment were randomly taken from the top, middle, and bottom of each clusters to determine berry detachment and skin rupture forces. For skin rupture force, a berry from each equatorial section was cradled in a jig attached to a force gauge (DPS-11; Imada, Northbrook, IL) and the gauge was gently inserted into the berry until the skin puncture (Fidelibus et al. 2007). The force required to puncture the skin of berry was recorded as the skin rupture force. The berry from the rachis section was then cradled in a jig attached to a force gauge (DPS-11; Imada, Northbrook, IL), and the rachis section was slowly pulled away from the berry until it detached. The force required to detach each berry from the rachis was recorded as the berry detachment force.

\section{Berry Color and Biochemical Quality Parameters}

The color parameters L (lightness), C (chroma) and Hue angle were measured at equatorial points on the berry surface of fifteen berries from each replication with a colorimeter (CR-400, Konica Minolta, Osaka, Japan) in reflectance mode. Around one hundred berries from nine representative clusters were collected for biochemical analyses. Total soluble solids content (SSC) expressed as ${ }^{\circ}$ Brix was measured with a portable refractometer (Atago, Tokyo, Japan) in grape juice obtained by whisking the berries from each replication in a blender and then filtering the juice. Titratable acidity (TA) was determined by titrating $10 \mathrm{~mL}$ of juice using $\mathrm{NaOH} 0.1 \mathrm{~mol} \mathrm{~L}^{-1}$ to $\mathrm{pH} 8.1$ (AOAC 1984). Results were expressed as g tartaric acid per $100 \mathrm{~g}$ fresh weight (FW). The $\mathrm{pH}$ was measured using a $\mathrm{pH}$ meter (Crison, Barcelona, Spain).

\section{Statistical Analyses}

Statistical analyses were performed in triplicate on three different batches. The mean values and standard deviation were calculated. The data shown in the figures are the average of all repetitions, where the error bars are the standard deviations. Experimental data were submitted to one-way analysis of variance and Student's t-test $(\mathrm{P}<0.05)$ using the software SPSS 13.0 for windows.

\section{Results and Discussion}

Berry decay rates during the intact (on vine) storage duration of grapes are presented in Fig. 2. During the first two months of storage duration, no significant changes were detected in decay rates of 'Alphonse Lavallée' and 'Narince' grape cultivars, with first month values $8.6 \%$ ('Narince')

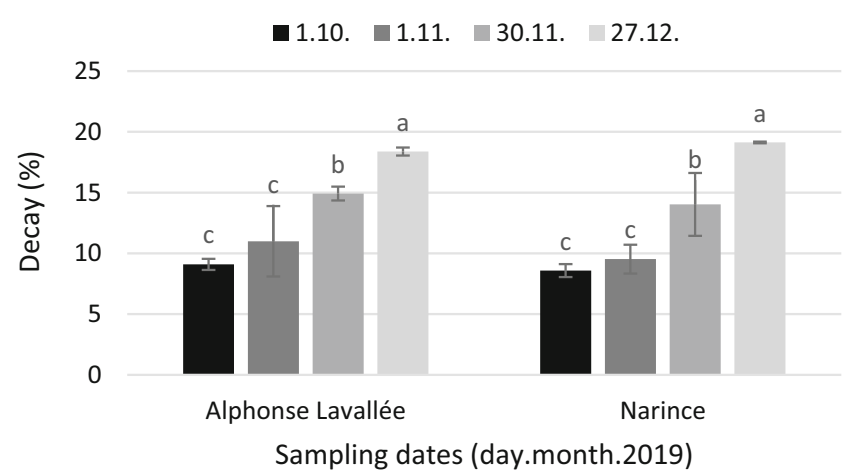

Fig. 2 Berry decay rates during the intact (on vine) storage duration of grapes. (Columns sharing different letters are significantly different from each other at $P<0.05$ )

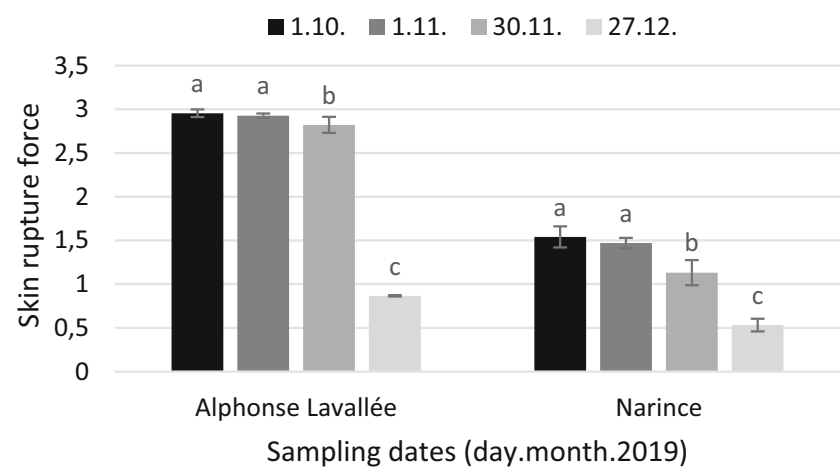

Fig. 3 Skin rupture force $(\mathrm{N})$ during the intact (on vine) storage duration of grapes. (Columns sharing different letters are significantly different from each other at $P<0.05$ )

and $9.1 \%$ ('Alphonse Lavallée'). After the second month of the study, progressive increases in berry decay occurred with significant changes, as expected. At the third analysis (30.11.2019), berry decay rates of 'Alphonse Lavallée' and 'Narince' grape cultivars were 14.9 and $14.0 \%$, respectively. Decay incidence in berries showed linear increase up to the end of study and reached to the values 18.4 and $19.1 \%$ for 'Alphonse Lavallée' and 'Narince', respectively. Controlling the decay incidence is one of the prime considerations in storages of the horticultural products, determining the storage success. Although, decay in perishable commodities such as grapes is inevitable during the storage (Pedreschi et al. 2013), certain treatments or cultivation practices have been applied to delay berry decay (Romanazzi et al. 2007; Sabir and Sabir 2013; Pastor et al. 2011; Youssef et al. 2015). Cultivar aptitude and ecological conditions have also significant effects on storage success. In the present study, conducted under temperate climate conditions of Konya Province, decay rates for both cultivars were under $10 \%$ for the first two months. At the end of four-month-storage duration, although numerically remarkable increments occurred in decay rates of grapes when compared to industrial cold storages, the 
Table 1 Changes in $\mathrm{L}^{*}, \mathrm{C}$ and Hue angle values of berries throughout the intact storage period

\begin{tabular}{lllll}
\hline Cultivars & Sampling dates (day.month.2019) & $\mathrm{L}$ & $\mathrm{C}$ & Hue \\
\hline 'A. Lavallée' & 01.10 .2019 & $30.60 \pm 0.36 \mathrm{a}$ & $2.84 \pm 0.22 \mathrm{a}$ & $281.69 \pm 09.24 \mathrm{~b}$ \\
& 01.11 .2019 & $28.87 \pm 0.50 \mathrm{~b}$ & $2.35 \pm 0.40 \mathrm{ab}$ & $296.88 \pm 11.54 \mathrm{a}$ \\
& 30.11 .2019 & $28.51 \pm 0.24 \mathrm{~b}$ & $2.16 \pm 0.11 \mathrm{~b}$ & $300.04 \pm 04.00 \mathrm{a}$ \\
& 27.12 .2019 & $27.72 \pm 0.15 \mathrm{c}$ & $1.97 \pm 0.39 \mathrm{~b}$ & $303.53 \pm 02.66 \mathrm{a}$ \\
$L S D_{(\% 5)}$ & & 0.64 & 0.58 & 14.63 \\
'Narince' & 01.10 .2019 & $37.55 \pm 1.12$ & $8.64 \pm 1.90$ & $116.47 \pm 2.05 \mathrm{a}$ \\
& 01.11 .2019 & $36.91 \pm 0.26$ & $8.11 \pm 0.35$ & $109.79 \pm 2.69 \mathrm{ab}$ \\
& 30.11 .2019 & $36.80 \pm 0.32$ & $7.70 \pm 0.40$ & $106.67 \pm 4.53 \mathrm{~b}$ \\
$L S D_{(\% 5)}$ & 27.12 .2019 & $36.47 \pm 0.04$ & $6.93 \pm 0.20$ & $95.20 \pm 5.55 \mathrm{c}$ \\
\hline
\end{tabular}

Means with different letters in a column are significantly different according to Student's t-test $(P<0.05)$

decayed berry rates were not above $20 \%$. Considering the increases in market values of table grapes during the autumn in Turkey, such decay values could be acceptable in traditional and organic maintenance of the grapes.

As depicted in Fig. 3, skin rupture force displaying considerable difference between the grape cultivars 'Alphonse Lavallée' and 'Narince', did not significantly change during the first two months. Berry skin rupturing force of 'Alphonse Lavallée' cultivar was remarkably high during the third months of the storage in comparison to previous study on cold storage of 'Crimson Seedless' grapes (Sabir and Sabir 2019), though significant decrease was detected in the third month. Similar pattern in skin rupture force for 'Narince' cultivar was also determined although the values were considerably lower than those of 'Alphonse Lavallée'. There were sharp decreases in skin rupture forces for both cultivars after the third month, possibly indicating the deadline for on-vine storage duration. Rupture (splitting) resistance of berry skin is one of the prima features directly affecting the phytopathological (Lang and During 1990) and food technological (Cagnasso et al. 2005) properties of table grapes because failure in rupture strength results in reduction of skin cell permeability that causes berry wa-

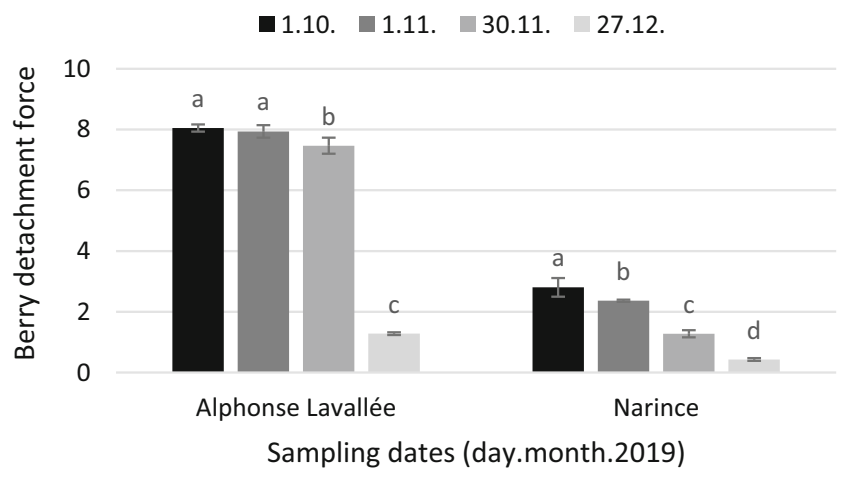

Fig. 4 Berry detachment force $(\mathrm{N})$ during the intact (on vine) storage duration of grapes. (Columns sharing different letters are significantly different from each other at $P<0.05$ ) ter loss. Therefore, grape cultivars with stronger berry skin would be more suitable for on-vine storage.

Findings on berry detachment force for both cultivars were just similar to those of skin rupture force as can be seen in Fig. 4. Berry detachment force (attachment strength of berry to pedicel and/or rachis) is one of the essential physiological features determining the shatter (loss of berries from the cap stem) incidence, an important postharvest disorders adversely affecting the market value of grapes (Crisosto et al. 2001; Carrillo et al. 2020). As expected, shatter increases in severity with increasing maturity, i.e., the longer the grape berry remains on the vine. In 'Alphonse Lavallee', there were no significant change in berry detachment force during the first two months and, after a slight decrease, it drastically decreased in the fourth month. Berry detachment force of 'Narince' cultivar presented a gradual decrease during the intact storage. Berry hardiness during storage, transporting and handling of table grapes is an important feature (Zoffoli et al. 2009), because water loss, pathogen inoculation and berry shattering are favored by berry damages.

Changes in different color coordinates on berry skin in response to prolonged intact storage are presented in Table 1 . $L$ and $C$ values gradually decreased during the storage of both cultivars. Changes in Hue angle values of the cultivars during the time course were opposite from each other, probably due to differences in their berry skin colors. Hue angle values of black colored 'Alphonse Lavallée' tended to increase along with the time course, although the increment magnitude was insignificant after the second month. Conversely, in 'Narince' cultivar with its yellow berries, Hue angle significantly decreased linearly during the storage. Changes in berry color due to desiccation, browning (Sabir et al. 2011) or non-enzymatic and enzymatic reactions is one of the common issues inevitably encountered during the storage (Pastor et al. 2011). Maintenance of the intact berry color of table grapes is one of the issues determining the storage success. 
Table 2 Changes in SSC ( ${ }^{\circ}$ Brix $)$, TA $(\%)$ and $\mathrm{pH}$ of berries throughout the intact storage period

\begin{tabular}{lllll}
\hline Cultivars & Sampling dates (day.month.2019) & SSC & TA & pH \\
\hline 'A. Lavallée' & 01.10 .2019 & $14.47 \pm 0.50 \mathrm{c}$ & $0.614 \pm 0.015 \mathrm{a}$ & $3.71 \pm 0.01 \mathrm{a}$ \\
& 01.11 .2019 & $14.60 \pm 0.40 \mathrm{c}$ & $0.589 \pm 0.015 \mathrm{ab}$ & $3.66 \pm 0.02 \mathrm{~b}$ \\
& 30.11 .2019 & $16.97 \pm 0.95 \mathrm{ab}$ & $0.577 \pm 0.008 \mathrm{~b}$ & $3.53 \pm 0.02 \mathrm{c}$ \\
& 27.12 .2019 & $17.40 \pm 0.20 \mathrm{a}$ & $0.457 \pm 0.002 \mathrm{c}$ & $3.34 \pm 0.01 \mathrm{~d}$ \\
$L S D_{(\% 5)}$ & & 1.10 & 0.021 & 0.03 \\
'Narince' & 01.10 .2019 & $20.17 \pm 0.25 \mathrm{~b}$ & $0.589 \pm 0.011 \mathrm{a}$ & $3.66 \pm 0.02 \mathrm{a}$ \\
& 01.11 .2019 & $20.27 \pm 0.12 \mathrm{~b}$ & $0.581 \pm 0.004 \mathrm{a}$ & $3.63 \pm 0.01 \mathrm{ab}$ \\
& 30.11 .2019 & $20.31 \pm 0.27 \mathrm{~b}$ & $0.567 \pm 0.002 \mathrm{~b}$ & $3.53 \pm 0.01 \mathrm{~b}$ \\
$L S D_{(\% 5)}$ & 27.12 .2019 & $23.50 \pm 0.50 \mathrm{a}$ & $0.418 \pm 0.002 \mathrm{c}$ & $3.17 \pm 0.04 \mathrm{c}$ \\
\hline
\end{tabular}

Means with different letters in a column are significantly different according to Student's t-test $(P<0.05)$

Changes in SSC, TA and $\mathrm{pH}$ values of grape must during the storage on vine are shown in Table 2. Generally, SSC in both cultivars underwent a slight but insignificant increase through the first two months of storage. A common increase in SSC is widespread in grapes after ripening (Sabir and Sabir 2013; Qin et al. 2015), due to gluconeogenesis, irreversible conversion pathway of organic acids to sugars (Hui et al. 2006), and water loss from berry surface (Sánchez-González et al. 2011). After the second month of on-vine maintenance, a significant increase occurred in 'Alphonse Lavallée' although such significant change was detected after the third month in 'Narince' cultivar. TA content of berries progressively decreased in both cultivars during storage with the highest decrease in the last month. The $\mathrm{pH}$ also underwent a general remarkable decrease along with the storage time similar to the results of Sabir and Sabir (2013) who stored the table grapes after harvest in cold room.

\section{Conclusion}

Conventional and organic foods have gained great attention due to their health benefits in accordance with the increasing living standards across the world. Consumer demands for healthy and antioxidant rich foods will probably further increase after global Covid-19 pandemic. Possibility to maintain the quality of grapes of 'Alphonse Lavallée' and 'Narince' cultivars on grapevines without any chemical treatments has been studied under vineyard conditions in temperate climate characteristics of Konya Province in Central Anatolia. Little losses in quality features were determined in both cultivars during until the 3rd sampling date (30.11.2019). In general, berry resistance features such as skin rupture force and berry detachment force did not show very drastic change, as high as losing the marketability during the three months. At the end of the study, at 4th moth (December) of on-vine storage, significant decay incidences were observed with similar patterns in cultivars. Investigations indicated that the grape clusters could be maintained on grapevines under intact condition of the cool autumn season in temperate zone by protecting them from the external damages using convenient covering materials up to three months depending on the response of cultivars to environmental variables. By this way, the grape growers could improve their viticulture income with a conventional, authentic and cost effective method, namely intact storage or on-vine storage.

Conflict of interest F. K. Sabir, A. Sabir and S. Unal declare that they have no competing interests.

\section{References}

Alexandratos N, Bruinsma J (2012) World agriculture towards 2030/ 2050: the saving water. From field to fork-curbing losses and wastage in the food chain 2012 revision. Working paper: FAO: ESA No. 12-03, p 4

AOAC (1984) Official methods of analysis, 4th edn. Association of Official Analytical Chemists, Arlington, pp 414-420

Cagnasso E, Caudana A, Rolle L, Gerbi V (2005) Profili di maturazione e scelta di vinificazione per la valorizzazione varietale. Inf Agrar Suppl (1-14):23-26

Carrillo N, Picolli P, Bottini R, Rodriguez J, Berli F (2020) Girdling of shoots at flowering reduces shatter in grapevine cv. Malbec. Aust J Grape Wine Res 26:102-109

Crisosto CH, Smilanick JL, Dokoozlian N (2001) Table grapes suffer water loss, stem browning during cooling delays. Calif Agric 55:39-42

Fidelibus MW, Cathline KA, Burns J (2007) Potential abscission agents for raisin, table, and wine grapes. Hort Sci 42:1626-1630

Hui YH, Nip WK, Nollet LML, Paliyath G, Simpson BK (2006) Food biochemistry and food processing. Blackwell, Ames, p 769

Kader AA (2002) Postharvest biology and technology: an overview. In: Kader AA (ed) Postharvest technology of horticultural crops. Publication 3311. University of California and Agricultural and Natural Resources, Berkeley, pp 145-148

Lang A, During H (1990) Grape berry splitting and some mechanical properties of the skin. Vitis 29:61-70

Lee JS, Kaplunov T, Zutahy Y, Daus A, Alkan N, Lichter A (2015) The significance of postharvest disinfection for prevention of internal decay of table grapes after storage. Sci Hortic 192:346-349 
Li L, Kaplunov T, Zutahy Y, Daus A, Porat R, Lichter A (2015) The effects of 1-methylcyclopropane and ethylene on postharvest rachis browning in table grapes. Postharvest Biol Technol 107:16-22

Pastor C, Sánchez-González L, Marcilla A, Chiralt A, Cháfer M, González-Martínez C (2011) Quality and safety of table grapes coated with hydroxypropyl methylcellulose edible coatings containing propolis extract. Postharvest Biol Technol 60:64-70

Pedreschi R, Lurie S, Hertog M, Nicolai B, Mes J, Woltering E (2013) Postharvest proteomics and food security. Proteomics 13:1772-1783

Piazzola F, Pati S, Amodio ML, Colelli G (2016) Effect of harvest time on table grape quality during on-vine storage. J Sci Food Agric 96:131-139

Qin X, Xiao H, Xue C, Yu Z, Yang R, Cai Z, Si L (2015) Biocontrol of graymold in grapes with the yeast Hanseniaspora uvarum alone and in combination with salicylic acid or sodium bicarbonate. Postharvest Biol Technol 100:160-167

Romanazzi G, Karabulut OA, Smilanick JL (2007) Combination of chitosan and ethanol to control postharvest gray mold of table grapes. Postharvest Biol Technol 45:134-140

Sabir FK, Sabir A (2013) Quality response of table grapes (Vitis vinifera L.) during cold storage to postharvest cap stem excision and hot water treatments. Inter. J Food Sci Technol 48:999-1006
Sabir FK, Sabir A (2017) Extending postharvest quality attributes of grapes (V. vinifera L. cv. 'Thompson Seedless') by preharvest calcium pulverizations. Acta Sci Pol Hortorum Cultus 16:29-38

Sabir FK, Sabir A (2019) Preharvest micronized calcium and postharvest UV-C treatments extend the quality of 'Crimson Seedless' (Vitis vinifera L.) grapes. Erwerbs-Obstbau 61(Suppl 1):25-32

Sabir A, Sabir FK, Kara Z (2011) Effects of modified atmosphere packing and honey dip treatments on quality maintenance of minimally processed grape cv. Razaki (V. vinifera L.) during cold storage. J Food Sci Technol 48:312-318

Sánchez-González L, Pastor C, Vargas M, Chiralt A, González-Martinez C, Cháfer M (2011) Effect of hydroxypropylmethyl cellulose and chitosan coatings with and without bergamot oil on quality and safety of cold-stored grapes. Postharvest Biol Technol 60:57-63

Youssef K, Roberto SR, Chiarotti F, Koyama R, Hussain I, de Souzac RT (2015) Control of Botrytis mold of the new seedless grape 'BRS Vitoria' during cold storage. Sci Hortic 193:316-321

Zoffoli J, Latorre BA, Rodriguez J, Aguilera JM (2009) Biological indicators to estimate the prevalence of gray mold and hairline cracks on table grapes cv. 'Thompson Seedless' after cold storage. Postharvest Biol Technol 52:126-133 